\title{
Technical Barriers and Development of Cu Wirebonding in Nanoelectronics Device Packaging
}

\author{
C. L. Gan, ${ }^{1,2}$ E. K. Ng, ${ }^{1}$ B. L. Chan, ${ }^{1}$ U. Hashim, ${ }^{2}$ and F. C. Classe ${ }^{1}$ \\ ${ }^{1}$ Spansion (Penang) Sdn Bhd, Phase II Free Industrial Zone, Penang, 119900 Bayan Lepas, Malaysia \\ ${ }^{2}$ Institute of Nanoelectronic Engineering (INEE), Universiti Malaysia Perlis, Perlis, 01000 Kangar, Malaysia
}

Correspondence should be addressed to C. L. Gan, clgan_pgg@yahoo.com

Received 26 May 2012; Accepted 30 July 2012

Academic Editor: Fathallah Karimzadeh

Copyright ( $) 2012$ C. L. Gan et al. This is an open access article distributed under the Creative Commons Attribution License, which permits unrestricted use, distribution, and reproduction in any medium, provided the original work is properly cited.

\begin{abstract}
Bondpad cratering, $\mathrm{Cu}$ ball bond interface corrosion, IMD (intermetal dielectric) cracking, and uncontrolled post-wirebond staging are the key technical barriers in $\mathrm{Cu}$ wire development. This paper discusses the UHAST (unbiased HAST) reliability performance of $\mathrm{Cu}$ wire used in fine-pitch BGA package. In-depth failure analysis has been carried out to identify the failure mechanism under various assembly conditions. Obviously green mold compound, low-halogen substrate, optimized Cu bonding parameters, assembly staging time after wirebonding, and anneal baking after wirebonding are key success factors for Cu wire development in nanoelectronic packaging. Failure mechanisms of $\mathrm{Cu}$ ball bonds after UHAST test and CuAl IMC failure characteristics have been proposed and discussed in this paper.
\end{abstract}

\section{Introduction}

$\mathrm{Cu}$ wirebonding is widely adopted in recent nanoelectronic packaging due to its conductivity, material properties, and cost effectiveness. However, there are few key technical barriers to be seriously considered in order to get a full transition from $\mathrm{Au}$ to $\mathrm{Cu}$ ball bonds in semiconductor packages. Postunbiased HAST $\mathrm{Cu}$ wire resistive open failures were widely investigated by researchers and mainly are attributed to $\mathrm{CuAl}$ IMC interface corrosion [1-6]. Chan [7], Chee [8], and Tan and Yarmo [9] found that silicon cratering is a failure mode as a result of overbonding parameter especially with $\mathrm{Cu}$ wire. Effects of molding compound $\mathrm{pH}$ level and $\mathrm{Cl}^{-}$content (in ppm) on UHAST reliability test have been investigated by $\mathrm{Su}$ [10]. Some researchers proposed palladium-coated $\mathrm{Cu}$ wire to be used instead of bare Cu wire [11]. Tan et al. [4] reported $\mathrm{Cu}$ ball bonds are more susceptible to $\mathrm{CuAl}$ corrosion cracking postreliability stress in such tests as Autoclave, HAST test, and HTSL (high temperature storage life). Yow and Eu [12, 13] reported on the implementation of an extra high temperature bake after wirebonding, but prior to encapsulation, to grow $\mathrm{CuAl}$ intermetallic layer and increase $\mathrm{Cu}$ ball strength. CuAl IMC formation dominates the bond reliability, and
IMC phases of $\mathrm{CuAl}$ have been widely investigated [14-19]. It is crucial to conduct and identify those key technical barriers with $\mathrm{Cu}$ wirebonding in nanoelectronic device packaging which will ensure successful $\mathrm{Cu}$ wirebonding deployment in high pin count and nanoscale devices. In this study, the bond reliability under different factors such as green and non-green package materials, optimized and excessive bonding conditions, assembly staging time, and resulting bond shear per square mil of $\mathrm{Cu}$ bond are investigated in the testing of UHAST. The failure mechanism at bond interface and proposal for resolving these technical barriers to $\mathrm{Cu}$ wirebonding are established.

\section{Experimental}

2.1. Materials and Preparation of $\mathrm{Cu}$ Wirebond Package with $90 \mathrm{~nm}$ Device. The key materials used include $0.8 \mathrm{mil} \mathrm{Cu}$ wire, fine pitch BGA packages, $90 \mathrm{~nm}$ low-k devices which were packaged into fortified fine pitch BGA package, and green $(<20 \mathrm{ppm}$ chloride in content $)$ and non-green ( $>20 \mathrm{ppm}$ or uncontrolled of chloride content) molding compound and substrates. The $90 \mathrm{~nm}$, low-k devices had 


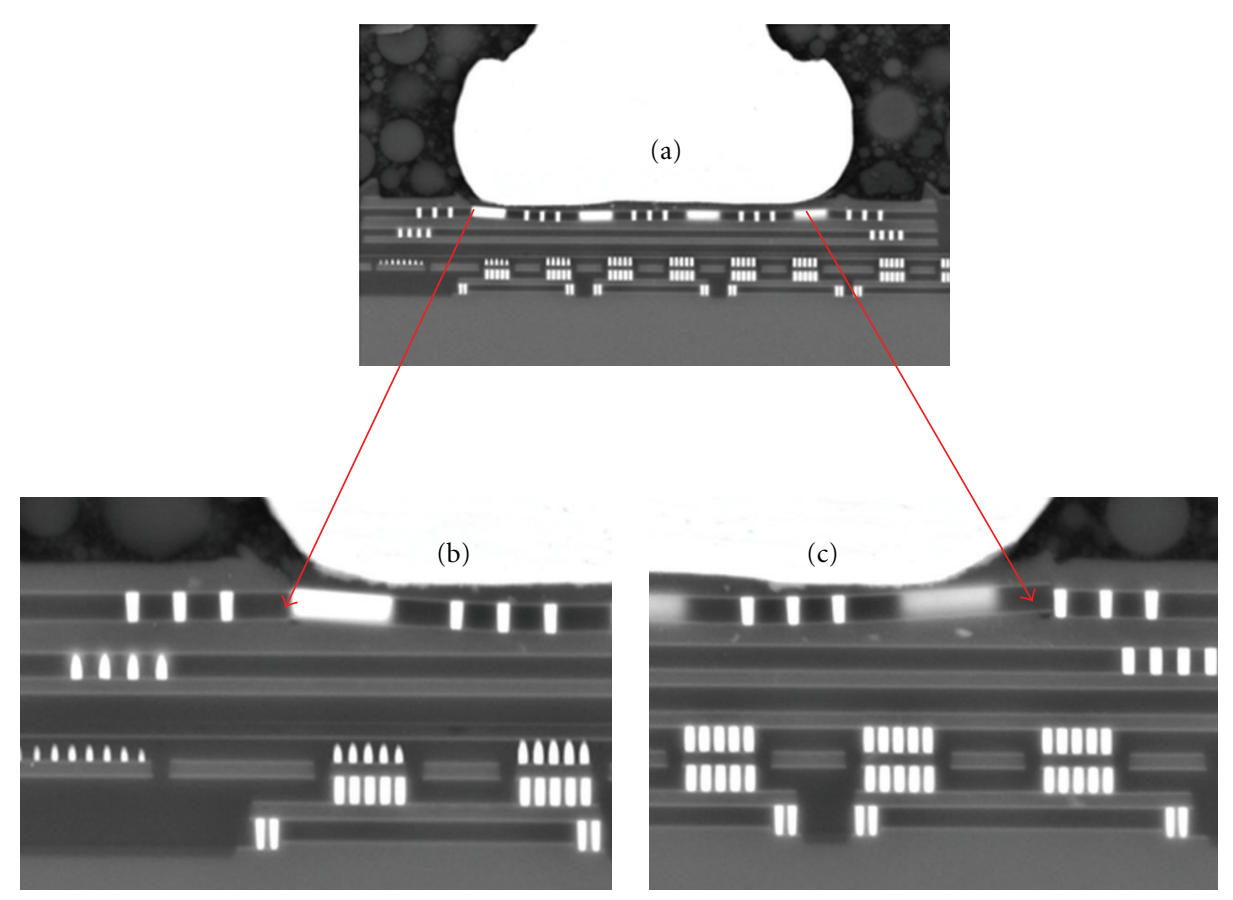

Figure 1: (a) Cratering at both Cu ball bond edges of leg no. 2 (b) and (c) IMD (Inter Metal Dielectric crater and crack) at silicon level.

top $\mathrm{Al}$ metallization bondpads of $0.80 \mathrm{um}$. In this $\mathrm{Cu}$ wire development study, there are total 7 legs comprising of bare $\mathrm{Cu}$ wire bonded on Fine pitch 64-ball BGA packages on a 2-layer substrate. The corresponding sample size is tabulated in Table 1. After electrical test, good samples were then subjected for preconditioning and 3-time reflow at $260^{\circ} \mathrm{C}$ as described in JEDEC IPC-STD 020 standard, followed by unbiased HAST (UHAST) stress testing per JESD22-118 at $\left(130^{\circ} \mathrm{C} / 85 \% \mathrm{RH}\right)[20]$. Electrical testing was conducted after 96 hours of stress to check $\mathrm{Cu}$ ball bond integrity in terms of its moisture reliability with various conditions. Results of UHAST reliability test of our evaluation are tabulated in Table 1 .

2.2. Reliability Testing of Nanoelectronic Package. As mentioned, prior to Unbiased HAST reliability stress test, the nanoelectronic packages were subjected to preconditioning $\left(30^{\circ} \mathrm{C}, 60 \% \mathrm{RH}\right)$ for 192 hours in a temperature and humidity chamber, followed by 3 cycles of reflow at $260^{\circ} \mathrm{C}$ by using reflow chamber as per JEDEC STD 020 standard. The moisture reliability testing was performed using a UHAST chamber and the sample electrical testing was performed at room and hot temperatures. First, samples were heated from room temperature and humidity to $130{ }^{\circ} \mathrm{C}$ and $85 \% \mathrm{RH}$ humidity. The samples were stressed in this environment for 96 hours. After 96 hours, electrical open, short, and device datasheet functionality was verified by using a commercial electrical tester. Microstructure of failing units was determined by using cross-section and SEM (scanning electron microscopy), and a chemical composition analysis was conducted by using EDX (energy dispersive X-ray).

\section{Results and Discussion}

\subsection{Silicon Cratering and IMD Cracking}

3.1.1. Key Challenges and Development. $\mathrm{Cu}$ wire is well identified as a harder material compared to Au wire in nanoelectronic packaging. Cratering (latent or otherwise) is one of the bonding failures attributed to over-bonding and appears as damage to the layers under bondpads $[1,2,9]$. Large stresses can be imparted on the layers under the bondpad as well as the silicon, leading to open failures. Sometimes, improper bonding over thin top Al metallization $(<1.0 \mu \mathrm{m}$ in thickness) will induce IMD (Inter-Metal Dielectric) cracking as depicted in Figure 1(a). It is crucial to implement optimized bonding parameters in devices with thin active circuits under bonding pads with $\mathrm{Cu}$ ball bonding $[2,3,7,8]$. In our evaluation, overbonding parameter in Leg no. 2 is found with UHAST $96 \mathrm{hr}$ opens which is attributed to IMD cracking as shown in Figures 1(a), 1(b), and 1(c).

According to the observation of Chen et al. after $\mathrm{Cu}$ wirebonding, there is a residual stress remaining around the perimeter of the $\mathrm{Cu}$ ball bond, primarily due to the capillary bonding pressure. The maximum residual stress gradient under pad occurs at the bond periphery [6] and is the primary root cause of IMD collapse and cracking beneath $\mathrm{Cu}$ ball bond. Hence it is a crucial step in $\mathrm{Cu}$ wirebonding development to identify and optimize the bonding parameter window in order to eliminate silicon cratering and IMD cracking. Severe IMD cracks may also cause cratering during wire pull test, and Tan and Yarmo [9] reported the silicon cratering during wire pull test after reliability tests. 
TABLE 1: Cu wirebonding reliability development study.

\begin{tabular}{|c|c|c|c|c|}
\hline Leg & Wire & Experimental parameter & Green/non-green materials & $\begin{array}{c}\text { UHAST } 96 \mathrm{hr} \text { results } \\
\text { (no. of failures/sample size) }\end{array}$ \\
\hline 1 & $\mathrm{Cu}$ wire & Nominal bonding parameter & $\begin{array}{l}\text { Green substrate } \\
\text { Green mold compound }\end{array}$ & $0 / 25$ \\
\hline 2 & $\mathrm{Cu}$ wire & High bonding parameter & $\begin{array}{l}\text { Green substrate } \\
\text { Green mold compound }\end{array}$ & $1 / 25$ \\
\hline 3 & Cu wire & Green mold compound (<20 ppm Cl$\left.{ }^{-}\right)$ & $\begin{array}{l}\text { Green substrate } \\
\text { Green mold compound }\end{array}$ & $0 / 50$ \\
\hline 4 & Cu wire & Non-green mold compound (>20 ppm Cl${ }^{-}$) & $\begin{array}{l}\text { Green substrate } \\
\text { Non-green mold compound }\end{array}$ & $31 / 50$ \\
\hline 5 & $\mathrm{Cu}$ wire & 3-days staging after wirebond & $\begin{array}{l}\text { Green substrate } \\
\text { Green mold compound }\end{array}$ & $0 / 50$ \\
\hline 6 & $\mathrm{Cu}$ wire & 7-days staging after wirebond & $\begin{array}{l}\text { Green substrate } \\
\text { Green mold compound }\end{array}$ & $2 / 50$ \\
\hline 7 & Cu wire & 10-days staging after wirebond & $\begin{array}{l}\text { Green substrate } \\
\text { Green mold compound }\end{array}$ & $1 / 50$ \\
\hline
\end{tabular}

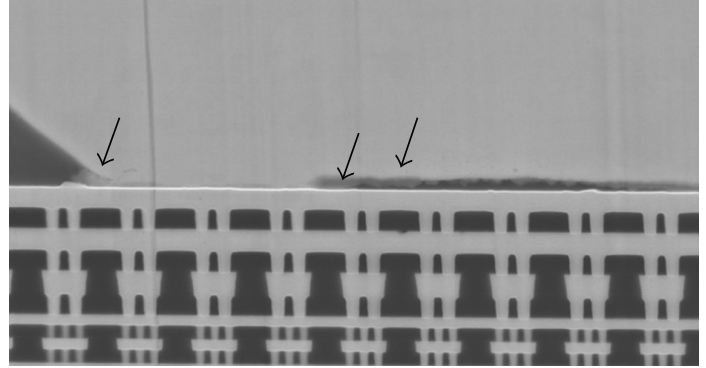

FIGURE 2: Initial CuAl IMC formation starts at both edges of Cu ball bond periphery.

Hang et al. posit that the deformation microstructures at $\mathrm{Cu}$ ball bond periphery also decrease the activation energy of metal atoms for interdiffusion and accelerate the initial $\mathrm{CuAl}$ IMC formation at the edge of $\mathrm{Cu}$ ball bond [14]. We also observed similar initial CuAl IMC formation at ball bond edges as shown in Figure 2.

\subsection{Effects of Green Packaging Material}

3.2.1. Green Molding Compound and Substrate. Leg no. 4 ( $\mathrm{Cu}$ wirebond package which is assembled with non-green molding compound) observed severe post-UHAST $96 \mathrm{hr}$ opens and $\mathrm{Cu}$ ball bond interfacial corrosion/cracking. Elemental analysis (EDX) was performed on failing $\mathrm{Cu}$ ball bonds and it revealed presence of 0.68 atomic $\%$ of $\mathrm{Cl}$ as indicated in Figure 3(a) and in Table 2. The presence of $\mathrm{Cl}$ in the EDX spectrum is believed to originate from the non green molding compound itself used in Leg 4.

Representative $\mathrm{Cu}$ ball bond FIB cross-section SEM images confirm $\mathrm{CuAl}$ interface corrosion/cracking as shown in Figure 3(b) The detail of the mechanism of $\mathrm{Cu}$ ball bond interfacial corrosion and later cracking with non-green molding compound is addressed in a subsequent section. However, the data indicate the importance of implementation of $\mathrm{Cu}$ wirebonding in nanoelectronic packaging with
TABLE 2: EDX analysis of CuAl IMC crack region post-UHAST $96 \mathrm{hr}$ opens: non-green mold compound (Leg 4).

\begin{tabular}{lcc}
\hline Leg & Element & Atomic \% \\
\hline & $\mathrm{O}$ & 8.64 \\
& $\mathrm{Al}$ & 8.17 \\
4 (non-green mold compound) & $\mathrm{Si}$ & 1.89 \\
& $\mathrm{Cl}$ & 0.68 \\
& $\mathrm{Cu}$ & 78.23 \\
& $\mathrm{Ta}$ & 2.40 \\
\hline
\end{tabular}

green molding compound and substrate material in BGA laminates.

There is no presence of $\mathrm{Cl}^{-}$in the $\mathrm{Cu}$ ball bond of UHAST $96 \mathrm{hr}$ survivors (for Leg 3 ). SEM cross-section results as shown in Figures 4(a), 4(b), and 4(c) for green mold compound leg (Leg no. 3) show normal IMC growth and solid bonding.

Confirmation on UHAST survivor from Leg 3 (Green mold compound) indicates no presence of $\mathrm{Cl}^{-}$element at center of $\mathrm{CuAl}$ IMC region. Table 3 tabulates the detailed EDX analysis results.

$\mathrm{Su}$ [10] reported that the green mold compound used in $\mathrm{Cu}$ wirebond package will affect the biased HAST reliability failure rate. The data indicated a striking effect on the reliability based on the $\mathrm{pH}$ and $\mathrm{Cl}$ content in mold compound. The lower the $\mathrm{pH}$ (more acidic) and the higher the $\mathrm{Cl}$ content are, the poorer the reliability is. CuAl IMCs are generally more susceptible to moisture corrosion and the impacts of corrosion have been reported in recent $\mathrm{Cu}$ ball bond studies $[1,4,5,10,21-23]$. Hence, green mold compound with a preferably low $\mathrm{Cl}$ content and high $\mathrm{pH}$ is recommended for use in $\mathrm{Cu}$ wirebonding for high volume manufacturing and to ensure moisture reliability performance.

\subsection{Effects of Post-Wirebond-Staging Time and Extra Thermal Treatment. It has been a challenge to ensure $\mathrm{Cu}$ ball bond} integrity in nanoelectronic packaging through various wire 


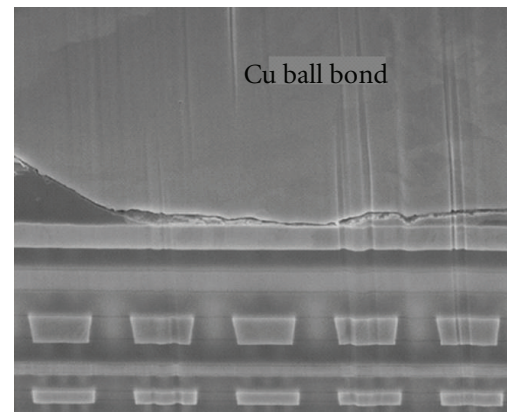

(a)

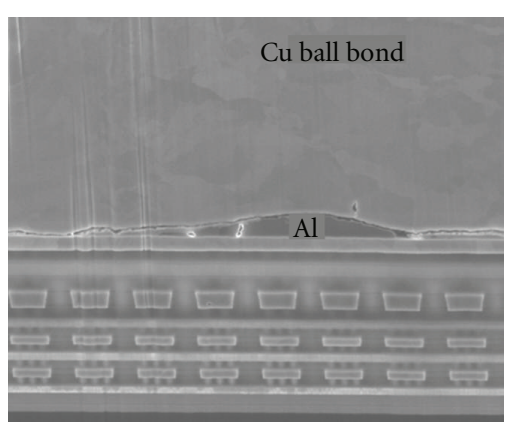

(b)

FIGURE 3: (a) CuAl IMC crack region post-UHAST $96 \mathrm{hr}$ opens (b) Cu ball bond corrosion and interface cracking between CuAl IMC of Leg no. 4.

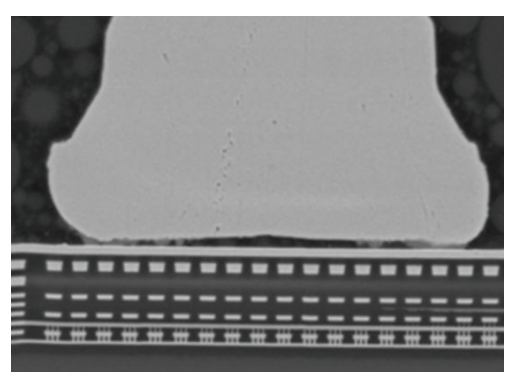

(a)

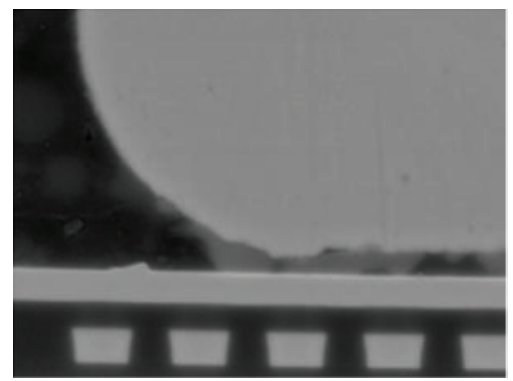

(b)

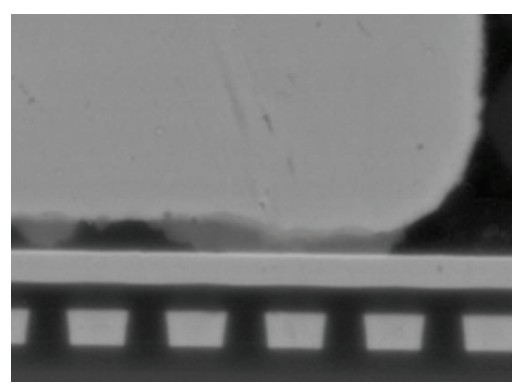

(c)

Figure 4: (a) Cu ball bond, (b) and (c) edges of $\mathrm{Cu}$ ball bonds-no $\mathrm{Cu}$ ball bond corrosion or weaknesses with Green molding compound (Leg no. 3).

TABle 3: EDX analysis of CuAl IMC crack region post-UHAST 96 hr opens: green mold compound (Leg 3).

\begin{tabular}{lcc}
\hline Leg & Element & Atomic \% \\
\hline & $\mathrm{O}$ & 1.48 \\
3 (Green mold compound) & $\mathrm{Al}$ & 11.02 \\
& $\mathrm{Si}$ & 0.98 \\
& $\mathrm{Cu}$ & 83.14 \\
& $\mathrm{Ta}$ & 3.38 \\
\hline
\end{tabular}

bonding enhancement approaches. Yow and Eu [12, 13] reported on the implementation of an extra high temperature baking post-wirebonding step prior to encapsulation to grow $\mathrm{CuAl}$ intermetallic layer and increase $\mathrm{Cu}$ ball strength. This can subsequently reduce $\mathrm{Cu}$ ball bond intrinsic stresses and in turn eliminate or mitigate bondpad cratering especially with harder $\mathrm{Cu}$ wire. The bake temperature can be as high as $125^{\circ} \mathrm{C}$ for 4 hours. Dry metal corrosion (oxidation in an $\mathrm{O}_{2}$-containing environment at high temperatures) results in a metal-oxide ( $\mathrm{MxOy}$ ) formation on the surface of the metal. In our case, Legs 5, 6, and 7 of $\mathrm{Cu}$ wirebonded units were staged at production floor for several days and subsequently sent through preconditioning and UHAST test to check the effects of assembly staging time on UHAST reliability performance (as tabulated in Table 1).

In our $\mathrm{Cu}$ wirebonding staging studies (Leg 5-7), wirebonded units were staged at the production floor for a number of days prior to package encapsulation or molding step. Assembly staging time should normally be closely monitored and controlled to prevent $\mathrm{Cu}$ ball bond oxidation at production floor, and based on the results of our evaluation (Leg no. 5 to Leg no. 7), it appears to be that the appropriate staging time after $\mathrm{Cu}$ wirebond step to encapsulation step should be gated to less than 3 days, as UHAST $96 \mathrm{hr}$ opens are observed with 7 days and 10 days of staging time. However, some industry data recommends bare $\mathrm{Cu}$ wire spool lifespan to be controlled less than 10 days on the factory floor [1]. The effect of assembly staging time on UHAST reliability of $\mathrm{Cu}$ ball bond is crucial to understand and could vary based on the assembly process and material set. The detailed failure mechanism is proposed as in (1) to (4) as follows:

$$
\mathrm{Cu}+\mathrm{O}_{2} \longrightarrow 2 \mathrm{CuO}
$$

(Cu oxide layer-dry metal oxidation),

$$
\mathrm{CuO}+\mathrm{H}_{2} \mathrm{O} \longrightarrow \mathrm{Cu}(\mathrm{OH})_{2}
$$

(wet corrosion and hydrolysis of $\mathrm{Cu}$ oxide under UHAST),

$$
\mathrm{Cu}_{9} \mathrm{Al}_{4}+4 \mathrm{O}_{2}+\mathrm{H}_{2} \mathrm{O} \longrightarrow 4 \mathrm{Al}+9 \mathrm{CuO}+\mathrm{H}_{2}
$$

(oxidation of $\mathrm{CuAl}$ IMC — in humid air environment),

$$
2 \mathrm{CuAl}_{2}+\frac{1}{2} \mathrm{O}_{2}+\mathrm{H}_{2} \mathrm{O} \longrightarrow 4 \mathrm{Al}+2 \mathrm{CuO}+\mathrm{H}_{2}
$$

(oxidation of $\mathrm{CuAl}$ IMC_-in humid air environment). 


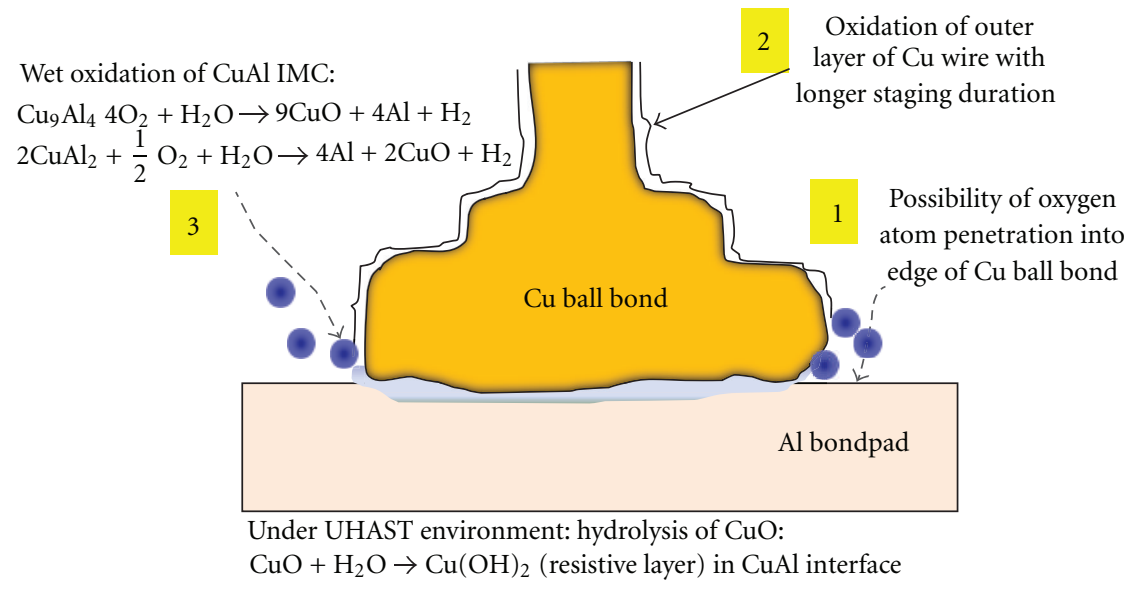

Figure 5: Proposed $\mathrm{Cu}$ ball bond oxidation mechanism due to long staging at production floor and induced resistive opens after UHAST reliability test.

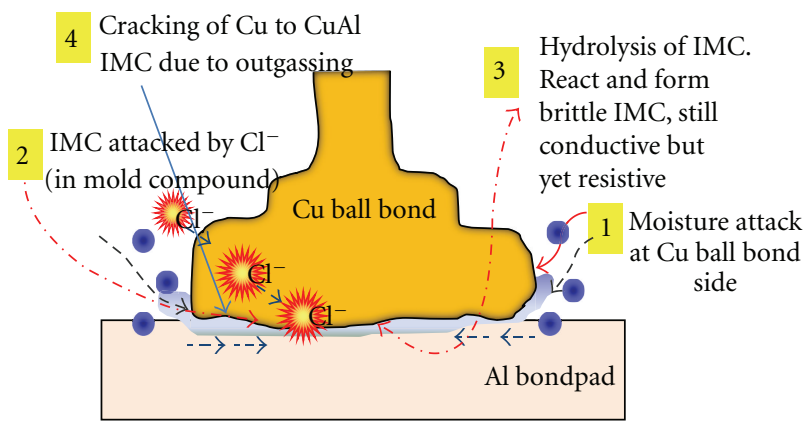

Figure 6: Proposed $\mathrm{Cu}$ ball bond corrosion failure mechanism in UHAST tests (Legs no. 4, 6, and 7).

Equation (2) reveals the wet oxidation of $\mathrm{CuO}$ to form $\mathrm{Cu}(\mathrm{OH})_{2}$ which is an insulative layer which will induce opens after UHAST stress test (as in Figure 5) [1,2]. Oxygen gas will penetrate into the edge of $\mathrm{Cu}$ ball bond and induce oxidation of $\mathrm{CuAl}$ IMC (in this case the majority of IMCs are $\mathrm{Cu}_{9} \mathrm{Al}_{4}$ and $\mathrm{CuAl}_{2}$ ) as shown in (3) and (4) [10]. Oxidation in humid air environment during staging will produce $\mathrm{CuO}$ which is a resistive layer in $\mathrm{CuAl}$ interface. $\mathrm{CuO}$ will undergo wet oxidation in UHAST test environmental test and $\mathrm{Cu}(\mathrm{OH})_{2}$ will be produced. This usually ended up with high peak of $\mathrm{O}$ in EDX analysis of an open failure after UHAST test. Our UHAST opens after UHAST $96 \mathrm{hr}$ also indicated presence of O peak (8.64 atomic \%) in Table 2.

\subsection{Failure Mechanisms of $\mathrm{Cu}$ Ball Bond Wet Corrosion under} UHAST. The Cu ball bond opens after unbiased HAST test mainly induced by $\mathrm{Cl}$ ionic content in mold compound. Figure 6 illustrates typical $\mathrm{Cu}$ ball bond failure mechanism. The initial formation of $\mathrm{CuAl}$ IMC beneath $\mathrm{Cu}$ ball bond is dominated by $\mathrm{Cu}_{9} \mathrm{Al}_{4}$ and $\mathrm{CuAl}_{2}[10]$. As mentioned before, $\mathrm{pH}$ and $\mathrm{Cl}$ ionic contents are critical parameters for mold compound.

Under unbiased HAST moist environment, ionic $\mathrm{Cl}$ attacks $\mathrm{Cu}_{9} \mathrm{Al}_{4}$ and $\mathrm{CuAl}_{2}$ IMC. The ionic $\mathrm{Cl}$ originates from the mold compound and forms an intermediate product of $\mathrm{AlCl}_{3}$ (reactive if under moisture environment such as unbiased HAST/PCT/biased HAST test) as shown in (5) and (6) below [21]. We propose the $\mathrm{Cl}^{-}$attack from the edge of $\mathrm{Cu}$ ball bond as indicated in Figure 7:

$$
\begin{gathered}
\mathrm{Cu}_{9} \mathrm{Al}_{4}+12 \mathrm{Cl}^{-} \longrightarrow 4 \mathrm{AlCl}_{3}+9 \mathrm{Cu} \\
\mathrm{CuAl}_{2}+6 \mathrm{Cl}^{-} \longrightarrow 2 \mathrm{AlCl}_{3}+\mathrm{Cu}
\end{gathered}
$$

Hydrolysis of IMC and $\mathrm{AlCl}_{3}$ (intermediate product) under a moisture-rich environment forms aluminium (III) oxide which is a resistive layer and ionic $\mathrm{Cl}$ is usually found at the corroded ball bond. $\mathrm{Cl}$ also has been found in our EDX analysis as shown in Figure 3(a). Equation (3) indicates the hydrolysis of $\mathrm{Cu}_{9} \mathrm{Al}_{4}$ into $\mathrm{Al}_{2} \mathrm{O}_{3}$ and outgassing:

$$
\mathrm{Cu}_{9} \mathrm{Al}_{4}+6 \mathrm{H}_{2} \mathrm{O} \longrightarrow 2\left(\mathrm{Al}_{2} \mathrm{O}_{3}\right)+6 \mathrm{H}_{2}+9 \mathrm{Cu}
$$

(outgassing which might cause IMC cracks),

$$
\mathrm{CuAl}_{2}+3 \mathrm{H}_{2} \mathrm{O} \longrightarrow \mathrm{Al}_{2} \mathrm{O}_{3}+\mathrm{Cu}+3 \mathrm{H}_{2}
$$

(outgassing which might cause IMC cracks),

$$
\begin{gathered}
2 \mathrm{AlCl}_{3}+3 \mathrm{H}_{2} \mathrm{O} \longrightarrow \mathrm{Al}_{2} \mathrm{O}_{3}+6 \mathrm{HCl} \\
\text { (acidic). }
\end{gathered}
$$

Cracking of the interface of $\mathrm{Cu}$ to the $\mathrm{Cu}$ IMC might be due to outgassing of $\mathrm{H}_{2}$ during hydrolysis (as shown in (7) and (8)) in between $\mathrm{Cu}$ IMC to Cu ball bonds. Cracking usually starts at $\mathrm{Cu}$ ball bond periphery and will propagate towards center of $\mathrm{Cu}$ ball bond [1]. Hence, it is advisable to utilize greener mold compound and low-halogen substrate materials in the substrate (solder mask material specifically) to be used for $\mathrm{Cu}$ wirebond packages. Equation (9) explains that aluminium trichloride will undergo hydrolysis under high humidity of UHAST ( $85 \% \mathrm{RH})$ and produce acidic environment. This also explains the $\mathrm{Cl}$ present in EDX analysis of corroded $\mathrm{Cu}$ ball bond with non-green mold compound. Tan et al. [4] described the corrosion mainly found 


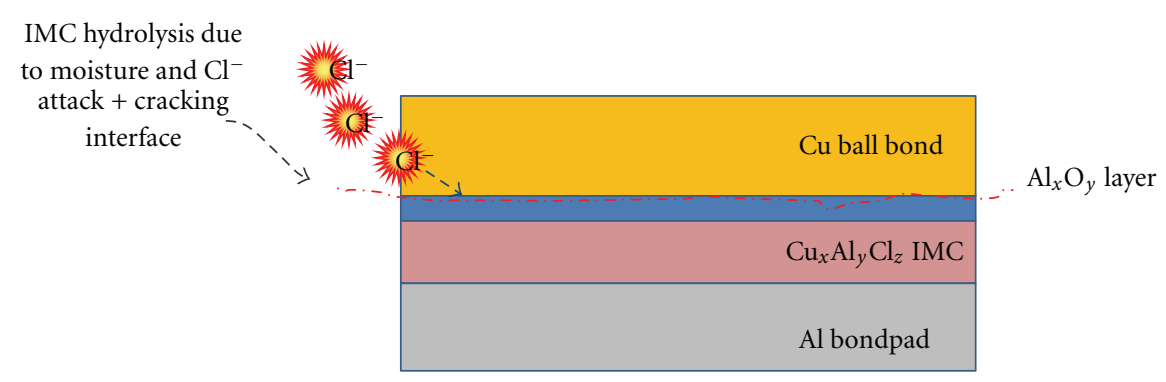

Figure 7: Proposed Cu ball bond corrosion failure mechanism in UHAST tests (Leg no. 4, 6, and Leg no. 7) $\mathrm{Cl}^{-}$attack from the edge of Cu ball bond.

at $\mathrm{CuAl}$ IMC interface. Hence, some researchers recommend Palladium-coated $\mathrm{Cu}$ wire to be deployed to minimize the $\mathrm{Cu}$ ball bond corrosion under moisture reliability condition $[2,11,22,24]$.

\section{Conclusion}

In $\mathrm{Cu}$ wirebonding evaluations on $90 \mathrm{~nm}$ devices, we have successfully identified the key technical barriers of $\mathrm{Cu}$ wire deployment in BGA laminate and its suitable package bill of material.

(1) Excessive ultrasonic bonding force will cause IMD cracks and in worse case silicon cratering will happen during wire pull $[1,2]$.

(2) Green molding compound (with high-pH and low$\mathrm{Cl}$ content) and low-halogen substrate material should be used in $\mathrm{Cu}$ wirebond package to ensure UHAST reliability $[1,10]$.

(3) Failure mechanism of post-UHAST $96 \mathrm{hr}$ open failures for $\mathrm{Cu}$ ball bond belongs to $\mathrm{CuAl}$ IMC interfacial corrosion and cracking. $\mathrm{Cu}_{9} \mathrm{Al}_{4}$ and $\mathrm{CuAl}_{2}$ react with ionic $\mathrm{Cl}$ to form $\mathrm{AlCl}_{3}$ which is reactive and will further react with moisture (in UHAST) to form a weak $\mathrm{Al}_{2} \mathrm{O}_{3}$ insulative layer.

(4) Assembly staging time should be controlled to 3 days or less after $\mathrm{Cu}$ wirebond step prior to molding. It is recommended to store unmolded units in an $\mathrm{N}_{2}$ cabinet [1].

(5) $\mathrm{Cu}$ ball bond oxidation mechanism is a combination of a dry oxidation process occurring at the $\mathrm{Cu}$ ball bond wire, forming a $\mathrm{CuO}$ liner oxide layer. The $\mathrm{CuAl}$ IMC $\left(\mathrm{Cu}_{9} \mathrm{Al}_{4}\right.$ and $\mathrm{CuAl}_{2}$ primarily) will react with $\mathrm{O}_{2}$ to form $\mathrm{CuO}$. $\mathrm{CuO}$ will undergo wet oxidation in UHAST test environmental test and $\mathrm{Cu}(\mathrm{OH})_{2}$ will be produced.

(6) Some industrial researchers reported an increase in $\mathrm{Cu}$ ball bond strength after an extra thermal treatment after $\mathrm{Cu}$ wirebonding. The bake temperature can be as high as $125^{\circ} \mathrm{C}$ for 4 hours baking duration in oven $[12,13]$.

\section{Acknowledgments}

The authors would like to take this opportunity to thank Spansion management (Gene Daszko, Chong HL, and Tony Reyes) for their support publication.

\section{References}

[1] C. L. Gan, T. T. Toong, C. O. Lim, and C. Y. Ng, "Environmental friendly package development by using copper wirebonding," in Proceedings of the 34th International Electronics Manufacturing Technology Conference (IEMT '10), December 2010.

[2] L. Charlie, "The challenges of copper wire bonding," in Proceedings of the 1st IEEE CPMT IMPACT, 2010.

[3] G. G. Harman, Wirebonding in Microelectronic: Materials, Processes, Reliability, and Yield, McGraw Hill, New York, NY, USA, 2nd edition, 1999.

[4] C. W. Tan, A. R. Daud, and M. A. Yarmo, "Corrosion study at $\mathrm{Cu}-\mathrm{Al}$ interface in microelectronics packaging," Journal of Applied Surface Science, vol. 191, no. 1-4, pp. 67-73, 2002.

[5] C. D. Breach and T. K. Lee, "Conjecture on the chemical stability and corrosion resistance of $\mathrm{Cu}-\mathrm{Al}$ and $\mathrm{Au}-\mathrm{Al}$ intermetallics in ball bonds," in Proceedings of the IEEE CPMT ICEPT-HDP, 2011.

[6] T. Boettcher, M. Rother, S. Liedtke et al., "On the intermetallic corrosion of $\mathrm{Cu}-\mathrm{Al}$ wire bonds," in Proceedings of the 12th Electronics Packaging Technology Conference (EPTC '10), pp. 585-590, December 2010.

[7] K. J. Chan, "Challenges of $\mathrm{Cu}$ wirebonding in low $\mathrm{k} / \mathrm{Cu}$ wafers with BOA structure," in Proceedings of the 60th IEEE CPMT ECTC, 2010.

[8] C. L. Chee, "Challenges of 43um Cu bonding on very thin \& Al bondpad structure," in Proceedings of the 60th IEEE CPMT ECTC, 2010.

[9] C. W. Tan and M. A. Yarmo, "Cratering on thermosonic copper wire ball bonding," Journal of Materials Engineering and Performance, vol. 11, no. 3, pp. 283-287, 2002.

[10] P. Su, "An evaluation of effects of molding compound properties on reliability of $\mathrm{Cu}$ wire components," in Proceedings of the 61st IEEE CPMT ECTC, 2011.

[11] L. J. Tang, H. M. Ho, W. Koh et al., "Pitfalls and solutions of replacing gold wire with palladium coated copper wire in IC wire bonding," in Proceedings of the 61st Electronic Components and Technology Conference (ECTC '11), pp. 1673-1678, June 2011.

[12] K. Y. Yow and P. L. Eu, "Cu wire bond reliability improvement through focused heat treatment after bonding," in Proceedings 
of the 33rd IEEE/CPMT International Electronics Manufacturing Technology Conference (IEMT '08), November 2008.

[13] K. Y. Yow and P. L. Eu, "Focused heat treatment after bonding for $\mathrm{Cu}$ wire bond reliability improvement," in Proceedings of the 10th Electronics Packaging Technology Conference (EPTC '08), pp. 965-970, December 2008.

[14] C. J. Hang, C. Q. Wang, M. Mayer, Y. H. Tian, Y. Zhou, and H. H. Wang, "Growth behavior of $\mathrm{Cu} / \mathrm{Al}$ intermetallic compounds and cracks in copper ball bonds during isothermal aging," Microelectronics Reliability, vol. 48, no. 3, pp. 416-424, 2008.

[15] H. J. Kim, J. Y. Lee, K. W. Paik et al., "Effects of $\mathrm{Cu} / \mathrm{Al}$ intermetallic compound (IMC) on copper wire and aluminum pad bondability," IEEE Transactions on Components and Packaging Technologies, vol. 26, no. 2, pp. 367-374, 2003.

[16] M. Drozdov, G. Gur, Z. Atzmon, and W. D. Kaplan, "Detailed investigation of ultrasonic Al-Cu wire-bonds-II. Microstructural evolution during annealing," Journal of Materials Science, vol. 43, no. 18, pp. 6038-6048, 2008.

[17] H. Xu, C. Liu, V. V. Silberschmidt, S. S. Pramana, T. J. White, and Z. Chen, "A re-examination of the mechanism of thermosonic copper ball bonding on aluminium metallization pads," Scripta Materialia, vol. 61, no. 2, pp. 165-168, 2009.

[18] J. Chen, D. Degryse, P. Ratchev, and I. De Wolf, "Mechanical issues of Cu-to-Cu wire bonding," IEEE Transactions on Components and Packaging Technologies, vol. 27, no. 3, pp. 539-545, 2004.

[19] M. K. Md Arshad, I. Ahmad, A. Jalar, G. Omar, and U. Hashim, "The effects of multiple zincation process on aluminum bond pad surface for electroless nickel immersion gold deposition," Journal of Electronic Packaging, Transactions of the ASME, vol. 128 , no. 3, pp. 246-250, 2006.

[20] JEDEC Specification JESD22A-118A, "Accelerated moisture resistance-Unbiased HAST Test," 2011.

[21] T. Uno, "Bond reliability under humid environment for coated copper wire and bare copper wire," Microelectronics Reliability, vol. 51, no. 1, pp. 148-156, 2011.

[22] Z. W. Zhong, "Overview of wire bonding using copper wire or insulated wire," Microelectronics Reliability, vol. 51, no. 1, pp. 4-12, 2011.

[23] C. D. Breach, "What is the future of bonding wire? Will copper entirely replace gold?" Gold Bulletin, vol. 43, no. 3, pp. 150$168,2010$.

[24] C. C. Lee, "Challenges of Pd-Coated Cu wirebonding on C65 $\mathrm{Al}$ bondpad low k/ Cu wafers with BOA structure," in Proceedings of the 13th IEEE CPMT EPTC, 2010. 

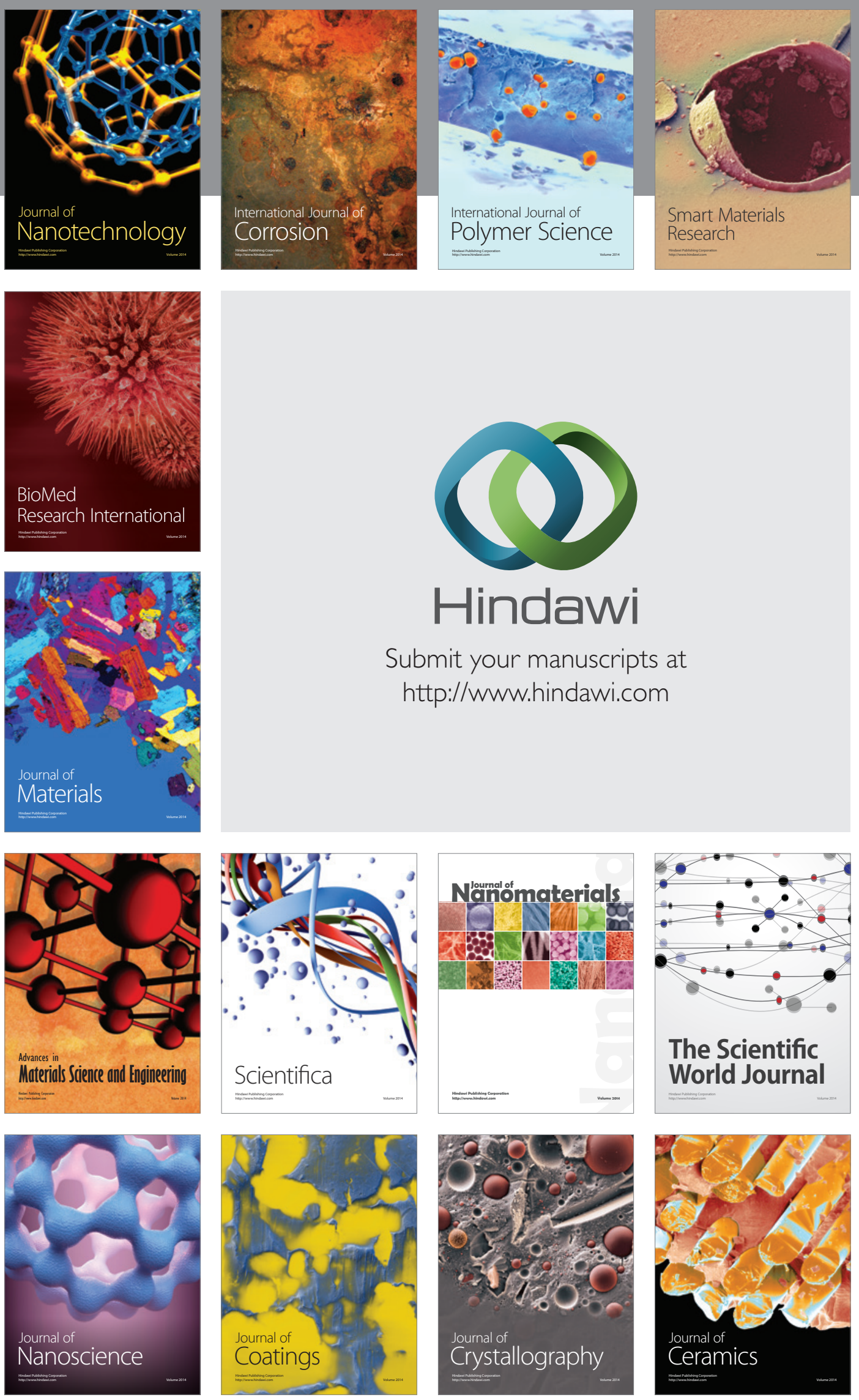

The Scientific World Journal

Submit your manuscripts at

http://www.hindawi.com

\section{World Journal}

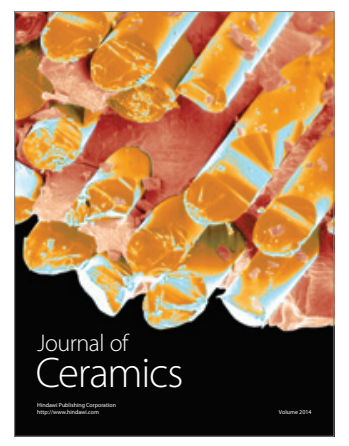

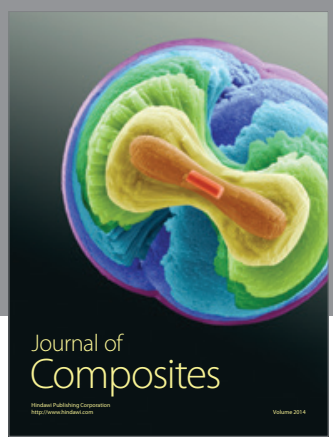
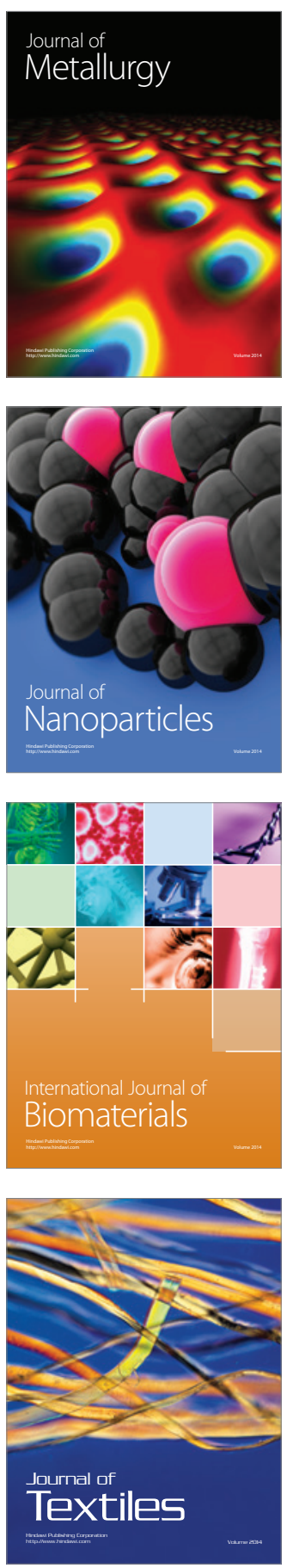